\title{
Delivery of sphingosine 1-phosphate from poly(ethylene glycol) hydrogels
}

\author{
Bradley K. Wacker, Evan A. Scott, Megan M. Kaneda, Shannon K. Alford, and Donald L. \\ Elbert \\ Department of Biomedical Engineering, Washington University in St. Louis, One Brookings Drive, \\ St. Louis, MO, 63130
}

\begin{abstract}
While protein growth factors promote therapeutic angiogenesis, delivery of lipid factors such as sphingosine 1-phosphate (S1P) may provide better stabilization of newly formed vessels. We developed a biomaterial for the controlled delivery of S1P, a bioactive lipid released from activated platelets. Multi-arm poly(ethylene glycol)-vinyl sulfone was crosslinked with albumin, a lipidtransporting protein, to form hydrogels. The rate of S1P release from the materials followed Fickian kinetics and was dependent upon the presence of lipid carriers in the release solution. Delivery of S1P from RGD-modified hydrogels increased the cell migration speed of endothelial cells growing on the materials. The materials also induced angiogenesis in the chorioallantoic membrane assay. Our data demonstrate that the storage and release of lipid factors provides a new route for the induction of angiogenesis by artificial materials.
\end{abstract}

\section{Introduction}

Angiogenesis is necessary to restore the blood supply to ischemic tissue and to generate complex engineered tissues. The formation of new blood vessels is a multistep process, occurring primarily at sites of vascular injury in adults, mediated by the temporally-controlled release of biological factors. ${ }^{1}$ Many of the factors that control angiogenesis are released from activated platelets, including platelet derived growth factor (PDGF), 2 vascular endothelial growth factor (VEGF), ${ }^{3}$ and basic fibroblast growth factor (bFGF), 4,5 as well as lipid factors such as sphingosine 1-phosphate (S1P) and lysophosphatidic acid. ${ }^{6,7}$ During angiogenesis, endothelial cells are initially stimulated to weaken cell-cell interactions, which increases vascular permeability. ${ }^{8,9}$ Endothelial cells then proliferate and migrate through the subendothelial matrix, forming sprouts from the wall of the original vessel. ${ }^{10}$ These sprouts develop into tube structures ${ }^{11}$ that are stabilized by the recruitment of mural cells to the outer surface of the tube of endothelial cells. ${ }^{6}$

Although delivery of bFGF and VEGF to tissues can promote angiogenesis, ${ }^{12-14}$ the newly formed vessels may regress over time. ${ }^{15,16} \mathrm{~S} 1 \mathrm{P}$ has been reported to be a complete angiogenic factor, ${ }^{17-19}$ regulating early stages of angiogenesis by promoting endothelial cell migration and proliferation, 20,21 and later stages by stimulating endothelial cell entubulation 22 and directing the stabilization of newly formed vessels. ${ }^{23,24}$ Knockout of the major endothelial cell $\mathrm{S} 1 \mathrm{P}$ receptor, $\mathrm{S}_{1} \mathrm{P}_{1}$, is lethal in mice at E12.5-14.5 due to incomplete vessel maturation, implying a role for S1P in recruiting mural cells, either directly or indirectly. ${ }^{25}$ The ability of S1P to stimulate multiple steps in angiogenesis, ${ }^{17,19}$ including the stabilization and maturation

* Corresponding author, Washington University in St. Louis, Department of Biomedical Engineering, Box 1097, One Brookings Drive, St. Louis, MO 63130., Phone: 314-935-7519, Fax: 314-935-7448, Email: elbert@ biomed.wustl.edu. 
of newly formed vessels, $2,24,25$ suggests that delivery of S1P from materials may provide a more effective route for the formation of a mature vasculature.

Due to the low solubility of S1P in aqueous solutions, its transport in the blood is facilitated by lipid-carriers. ${ }^{26,27}$ The majority of S1P in the blood is bound to albumin and high-density lipoproteins (HDL) via affinity interactions. ${ }^{28}$ These reversible interactions could be used as a means of controlling S1P release from artificial materials. However, previous attempts to use the binding properties of albumin to achieve controlled delivery led to the complete release of theophylline, acetaminophen and hydrocortisone in 9 hours. ${ }^{29}$

Poly(ethylene glycol) (PEG) materials display a resistance to protein adsorption 30 and versatility in the incorporation of biological factors. ${ }^{31,32}$ Conversion of the endgroups on PEG to Michael-type acceptors allows the addition of peptides or other biological factors to the materials via conjugate addition reactions. ${ }^{32}$ Vinyl sulfone endgroups provide high reactivity and a high specificity towards thiols at neutral $\mathrm{pH}$, without a competing hydrolysis reaction. Additionally, reaction of vinyl sulfone with amines in a slightly basic environment is feasible, allowing for reaction of PEG with lysine groups in proteins. 33,34

By crosslinking PEG-vinyl sulfone with albumin, we have developed a new biomaterial for the delivery of the potent angiogenic lipid S1P. Albumin within these hydrogels sequesters S1P and controls its release. Here we demonstrate the controlled delivery of S1P from PEG hydrogels, the enhancement of endothelial cell migration on the materials in vitro, and the induction of angiogenesis in the chorioallantoic membrane (CAM) assay.

\section{Methods PEG synthesis}

PEG-octavinyl sulfone (PEG-OVS) was synthesized from eight-arm PEG-OH (mol. wt. 10,000 , Shearwater Polymers, Huntsville, AL) in four steps using a modification of the methods described by Morpurgo et al. ${ }^{34}$ In the first step, PEG-mesylate was formed by the reaction of mesyl chloride with PEG under nitrogen. PEG ( $25 \mathrm{~g}$ ) dissolved in $300 \mathrm{~mL}$ toluene was dried by azeotropic distillation until the final volume was $150 \mathrm{~mL}$. After cooling, $50 \mathrm{~mL}$ of dichloromethane (DCM) was added to prevent precipitation of PEG. The solution was cooled on ice for $15 \mathrm{~min}$, and $5.58 \mathrm{~mL}$ triethylamine (TEA, 2 equiv.) was added. Next, $3.10 \mathrm{~mL}$ methane sulfonyl chloride ( 2 equiv.) was added dropwise and allowed to react for $20 \mathrm{~h}$. The TEA salt was filtered out, and the total volume was reduced to approx. $20 \mathrm{~mL}$ by rotary evaporation. PEG was precipitated by addition of ice-cold diethyl ether, recovered by filtration, and dried under vacuum: ${ }^{1} \mathrm{H}$ NMR $\left(\mathrm{CDCl}_{3}\right) 3.13 \mathrm{ppm}\left(\mathrm{s}, 3 \mathrm{H},-\mathrm{SO}_{2} \mathrm{CH}_{3}\right), 3.61 \mathrm{ppm}(\mathrm{PEG}$ backbone), $4.35 \mathrm{ppm}\left(\mathrm{t}, 2 \mathrm{H},-\mathrm{CH}_{2} \mathrm{OSO}_{2}\right.$ ). In the second step, PEG-mesylate was reacted with $\beta$-mercaptoethanol to form PEG-hydroxyethylsulfide. The PEG-mesylate $(15.5 \mathrm{~g})$ was dissolved in $150 \mathrm{~mL}$ sodium borate buffer $(50 \mathrm{mM}, \mathrm{pH} 8), 3.5 \mathrm{~mL}$ of $14.3 \mathrm{M} \beta$-mercaptoethanol (4 equiv.) was added, and the solution was allowed to react at reflux under nitrogen for $3 \mathrm{~h}$. The PEG was extracted twice with DCM, and the volume was reduced to approx. $20 \mathrm{~mL}$ by rotary evaporation. PEG was precipitated by addition of ice-cold diethyl ether, recovered by filtration, and dried under vacuum: ${ }^{1} \mathrm{H}$ NMR $\left(\mathrm{CDCl}_{3}\right) 2.72 \mathrm{ppm}\left(\mathrm{t}, 2 \mathrm{H},-\mathrm{CH}_{2} \mathrm{~S}-\right), 2.75 \mathrm{ppm}(\mathrm{t}$, $2 \mathrm{H},-\mathrm{SCH}_{2}-$ ), $3.61 \mathrm{ppm}$ (PEG backbone). Next, the sulfide was oxidized using hydrogen peroxide to form PEG-hydroxyethylsulfone. PEG-hydroxyethylsulfide $(12.79 \mathrm{~g})$ was dissolved in $50 \mathrm{~mL}$ distilled water with $1.69 \mathrm{~g}$ sodium tungstate ( 0.5 equiv.). The solution was cooled to near $0{ }^{\circ} \mathrm{C}$ and reacted with $2.09 \mathrm{~mL} 30 \%$ hydrogen peroxide (2 equiv.) overnight on ice. The PEG was extracted twice with DCM. The total volume of DCM was reduced to approx. $20 \mathrm{~mL}$ by rotary evaporation. PEG was precipitated by addition of ice-cold diethyl ether, recovered by filtration, and dried under vacuum: ${ }^{1} \mathrm{H}$ NMR $\left(\mathrm{CDCl}_{3}\right) 3.32 \mathrm{ppm}\left(\mathrm{t}, 2 \mathrm{H},-\mathrm{CH}_{2} \mathrm{SO}_{2^{-}}\right), 3.39$ ppm (t, $\left.2 \mathrm{H},-\mathrm{SO}_{2} \mathrm{CH}_{2}-\right), 3.61 \mathrm{ppm}$ (PEG backbone), $3.92 \mathrm{ppm}\left(\mathrm{t}, 2 \mathrm{H},-\mathrm{OCH}_{2} \mathrm{CH}_{2} \mathrm{SO}_{2^{-}}\right), 4.03$ 
ppm (t, $2 \mathrm{H},-\mathrm{SO}_{2} \mathrm{CH}_{2} \mathrm{CH}_{2} \mathrm{OH}$ ). In the final step, the hydroxyethylsulfone was converted to a vinyl sulfone. PEG-hydroxyethylsulfone $(7.97 \mathrm{~g})$ was dried by azeotropic distillation in toluene until the final volume was $150 \mathrm{~mL}$. After cooling, $50 \mathrm{~mL}$ DCM was added to prevent precipitation of the PEG. The solution was cooled on ice for $15 \mathrm{~min}$, then $2.68 \mathrm{~mL}$ TEA ( 3 equiv.) was added. Next, $0.75 \mathrm{~mL}$ mesyl chloride (1.5 equiv.) was added dropwise, and the solution was allowed to react for $24 \mathrm{~h}$. Another $2.68 \mathrm{~mL}$ TEA ( 3 equiv.) was added, followed by $0.75 \mathrm{~mL}$ mesyl chloride ( 1.5 equiv. added dropwise), and the reaction was carried out overnight. The TEA salt was filtered out and the total volume was reduced to approx. $20 \mathrm{~mL}$ by rotary evaporation. PEG was precipitated by addition of ice-cold diethyl ether, recovered by filtration, and dried under vacuum: ${ }^{1} \mathrm{H}$ NMR $\left(\mathrm{CDCl}_{3}\right) 3.61 \mathrm{ppm}$ (PEG backbone), $6.04 \mathrm{ppm}$ $\left(\mathrm{d}, 1 \mathrm{H},=\mathrm{CH}_{2}\right), 6.35 \mathrm{ppm}\left(\mathrm{d}, 1 \mathrm{H},=\mathrm{CH}_{2}\right), 6.79 \mathrm{ppm}\left(\mathrm{q}, 1 \mathrm{H},-\mathrm{SO}_{2} \mathrm{CH}=\right)$. PEG-tetravinyl sulfone (PEG-TVS) was synthesized from four-arm PEG (mol. wt. 10,000, Shearwater Polymers) using the same protocol with $80 \%$ end group conversion by NMR. PEG-diamine was synthesized as previously described ${ }^{32}$ from poly(ethylene glycol), mol. wt. 3400 (24 g, Sigma, St. Louis, MO, USA): ${ }^{1} \mathrm{H}$ NMR (CDCl3) $2.85 \mathrm{ppm}$ (t, $\left.4 \mathrm{H},-\mathrm{CH}_{2}-\mathrm{NH}_{2}\right), 3.65 \mathrm{ppm}$ (PEG backbone). End group conversion was $99.1 \%$ as shown by NMR.

\section{Hydrogel Formation}

Hydrogels were formed by a conjugate addition reaction between PEG-OVS and: (1) PEGdiamine, (2) fatty acid-free bovine serum albumin (FAF-BSA), (3) bovine fibrinogen, or (4) dithiothreitol (DTT). DTT was dissolved in phosphate buffered saline (PBS; $137 \mathrm{mM} \mathrm{NaCl}$, $8 \mathrm{mM} \mathrm{Na}_{2} \mathrm{HPO}_{4} \cdot 7 \mathrm{H}_{2} \mathrm{O}, 0.7 \mathrm{mM} \mathrm{CaCl}_{2}, 2.7 \mathrm{mM} \mathrm{KCl}, 1.5 \mathrm{mM} \mathrm{KH}_{2} \mathrm{PO}_{4}, 0.5 \mathrm{mM} \mathrm{MgCl}_{2} ; \mathrm{pH}$ 7.4) at $0.3 \mathrm{mg}$ per $10 \mu \mathrm{L}$ PBS. All other precursors were dissolved in PBS by adding $10 \mathrm{mg}$ solid to $50 \mu \mathrm{L}$ PBS at $\mathrm{pH} 8.0$ (assuming a volume change due to the dissolved precursors to be $1 \mu \mathrm{L}$ per mg of solid, the precursors were nominally dissolved at $10 \mathrm{mg} / 60 \mu \mathrm{L}$ ). PEG-OVS was then mixed with crosslinking molecules at a 1:1 ratio of vinyl sulfone to amine. For albumin and fibrinogen, this ratio was estimated by analyzing the 3D crystal structures of the proteins (Protein Databank IDs: 1AO6 and 1DEQ, respectively) with the Deep View Swiss-Pdb Viewer using the default accessibility option in the software. This analyzes lysines based on surface area solvent accessibility of the residue, but does not necessarily indicate the availability of the amine for reaction with a vinyl sulfone. For albumin, 36 of the 59 lysines were accessible, while for fibrinogen 65 of 106 were accessible. Optimal ratios of reactants were then determined empirically for each crosslinker by forming gels with different ratios of each component, seeking to minimize the amount of gel swelling in PBS after crosslinking. For PEG-OVS/PEG-diamine gels, $50 \mu \mathrm{L}$ PEG-OVS $(\sim 8.3 \mathrm{mg})$ was mixed with $68 \mu \mathrm{L}$ PEG-diamine $(\sim 11.3 \mathrm{mg})$. For PEG-OVS/albumin gels, the final mixture consisted of $40 \mu \mathrm{L}$ PEG-OVS ( 6.6 $\mathrm{mg})$ and $60 \mu \mathrm{L}$ albumin $(\sim 10.0 \mathrm{mg})$. For PEG-OVS/fibrinogen, the final ratio was $20 \mu \mathrm{L}$ PEGOVS $(\sim 3.3 \mathrm{mg})$ to $50 \mu \mathrm{L}$ fibrinogen $(\sim 8.3 \mathrm{mg})$. After mixing the precursors, gels were formed in tissue culture plate wells, or, for thin layer chromatography, the scrape wound assay, or the chorioallantoic membrane assay, between glass microscope slides. For the latter method, the solution was pipetted onto the center of a glass microscope slide made hydrophobic with SigmaCote (Sigma, St. Louis, MO). Another hydrophobic slide was clamped on top, using 0.7 $\mathrm{mm}$ thick Teflon spacers at the edges of the slides. The solution contacted only hydrophobic glass and formed a circular disc. The solutions were crosslinked in a $37{ }^{\circ} \mathrm{C}$ humidified incubator for $24 \mathrm{~h}$. The gels were then swollen in PBS overnight.

\section{PEG hydrogel swelling}

PEG hydrogels ( $50 \mu \mathrm{L}$ ) were formed using PEG-OVS and PEG-TVS crosslinked with albumin, fibrinogen, PEG-diamine, or DTT. The hydrogels were swollen in PBS for $96 \mathrm{~h}$ and each gel was weighed to determine the swollen volume. Densities used in the calculation of volume fractions were: PBS, $1.017 \mathrm{~g} / \mathrm{mL}$; PEG, $1.199 \mathrm{~g} / \mathrm{mL}$; albumin, $1.364 \mathrm{~g} / \mathrm{mL}$; fibrinogen, 1.379 $\mathrm{g} / \mathrm{mL}$; and DTT, $1.000 \mathrm{~g} / \mathrm{mL}$. 


\section{PEG hydrogel mesh size estimated using electrophoresis}

A modified SDS-PAGE gel was used to characterize albumin diffusion through PEG hydrogels. A 15\% acrylamide gel was formed at the bottom of the casting chamber, with a spacer to form a well on the left side of the gel. After the acrylamide solidified, the PEG-OVS/ albumin precursor solution was pipetted into the formed well. The casting stand was placed in a humidified $37^{\circ} \mathrm{C}$ incubator for $24 \mathrm{~h}$ to crosslink the PEG gel. A 7\% acrylamide gel was formed over the polymerized gels, followed by a stacking gel.

\section{S1P loading}

PEG hydrogels were loaded with S1P using two methods: 'postloading' and 'preloading'. PEG hydrogels were 'postloaded' with S1P by passive diffusion, incubating the formed gels with $500 \mu \mathrm{L} 10 \mu \mathrm{M}$ S1P (5 nmol) in PBS containing 0.01\% (w/v) FAF-BSA. Following $24 \mathrm{~h}$ of incubation with S1P, gels were washed in PBS twice for $1 \mathrm{~h}$ and then once for $24 \mathrm{~h}$. PEG hydrogels were 'preloaded' with S1P by reacting a solution of PEG-OVS with a solution containing a crosslinker premixed with $5 \mathrm{nmol} \mathrm{S1P}$. S1P-preloaded gels were washed in PBS twice for $1 \mathrm{~h}$ and then once for $24 \mathrm{~h}$.

\section{Thin layer chromatography (TLC)}

After washing in PBS, $150 \mu \mathrm{L}$ S1P-loaded gels were placed into Eppendorf tubes containing $500 \mu \mathrm{L} 0.4 \%$ FAF-BSA in PBS, which was vortexed for $24 \mathrm{~h}$. A small sample of the PBS (5 $\mu \mathrm{L}$ ) was removed from each Eppendorf tube and loaded on a silica TLC plate (Whatman, Inc., Clifton, New Jersey). The plates were developed in butanol:acetic acid:water (3:3:1). For visualization, the TLC plate was sprayed with ninhydrin reagent $(0.2 \mathrm{~g}$ ninhydrin in $100 \mathrm{~mL}$ butanol) and heated.

\section{[32P]S1P Release}

Radiolabeled S1P was produced using the methods of Olivera et al. ${ }^{35}$ Briefly, $10 \mu 1$ of $10 \mathrm{mM}$ sphingosine (BioMol, Plymouth Meeting, PA) in buffer A (25 mM Tris HCl, pH 7.4, 10\% (v/ v) glycerol, $0.05 \%$ Triton X-100, $1 \mathrm{mM}$ DTT) containing $0.4 \%$ BSA was added to $80 \mu \mathrm{L}$ sphingosine kinase ( $3.6 \mathrm{mg} / \mathrm{mL}$ in buffer A), and $90 \mu \mathrm{L}$ buffer A. The reaction was started by adding $20 \mu \mathrm{L}\left[{ }^{32} \mathrm{P}\right] \mathrm{ATP}(100 \mu \mathrm{Ci}, 10 \mathrm{mM}$, MP Biomedicals, Irvine, CA $)$ in $100 \mathrm{mM} \mathrm{MgCl}$. The reaction was incubated overnight at $37^{\circ} \mathrm{C}$ and stopped by the addition of $20 \mu \mathrm{L}$ of $1 \mathrm{M}$ $\mathrm{HCl}$. Lipids were extracted with $800 \mu \mathrm{L}$ chloroform/methanol/1 M HCl (100:200:1). After mixing, $240 \mu \mathrm{L}$ chloroform and $240 \mu \mathrm{L} 2 \mathrm{M} \mathrm{KCl}$ were added and the solution was centrifuged. The aqueous phase was removed, and the organic phase was extracted again by the addition of $400 \mu \mathrm{L} \mathrm{1:1} \mathrm{methanol/1} \mathrm{M} \mathrm{HCl.} \mathrm{The} \mathrm{phases} \mathrm{were} \mathrm{separated} \mathrm{by} \mathrm{centrifugation.} \mathrm{The} \mathrm{organic}$ phase was removed, dried under nitrogen flow, and dissolved in PBS containing FAF-BSA. For gels postloaded with S1P after crosslinking, $\left[{ }^{32} \mathrm{P}\right] \mathrm{S} 1 \mathrm{P}$ was dissolved in PBS containing $0.01 \%$ FAF-BSA and added to $50 \mu \mathrm{L}$ PEG hydrogels in a 24 -well plate for $24 \mathrm{~h}$. For gels formed from albumin preloaded with S1P, $\left.{ }^{32} \mathrm{P}\right] \mathrm{S} 1 \mathrm{P}$ was dissolved in $570 \mu \mathrm{L}$ PBS containing $95 \mathrm{mg}$ FAF-BSA. Aliquots were mixed with PEG-OVS and incubated for $24 \mathrm{~h}$ to form S1Pcontaining hydrogels ( $50 \mu \mathrm{L}$ total volume) on the bottoms of wells in a $24-w e l l$ plate. The S1Ploaded hydrogels were washed twice in $1 \mathrm{~mL}$ PBS for $1 \mathrm{~h}$ (to remove unbound S1P) and a third time for $24 \mathrm{~h}$. Next, $1.5 \mathrm{~mL}$ of platelet poor plasma (PPP) or PBS containing $0 \%, 0.4 \%$, or $4 \%$ (w/v) FAF-BSA was added to the gels. The solutions were removed from the wells and replaced with fresh solutions at $1,3,6,12$, and $24 \mathrm{~h}$ and the release of [ $\left.{ }^{32} \mathrm{P}\right] \mathrm{S} 1 \mathrm{P}$ was quantified by scintillation counting. The release at each time point is reported as a fraction of total S1P in each gel, which was determined by summing the amount of S1P in all wash and release solutions for each gel and the amount of S1P in each gel at the end of the experiment. PPP was obtained from human subjects with informed consent in accordance with Washington University Medical Center guidelines (Human Studies Committee Approval \#04-097). 


\section{Cell culture}

All cell culture reagents were purchased from Sigma (St. Louis, MO) unless otherwise noted. Human umbilical vein endothelial cells (HUVEC) were purchased from Clonetics, Inc (Walkersville, MD) and cultured in MCDB 131 medium supplemented with 2\% FBS, $10 \mathrm{ng} /$ $\mathrm{mL}$ epidermal growth factor, $10 \mu \mathrm{g} / \mathrm{mL}$ heparin, $1.0 \mu \mathrm{g} / \mathrm{mL}$ hydrocortisone, $1 \%$ antibioticantimycotic (ABAM, 100x) solution (Invitrogen, Carlsbad, CA), and $6 \mathrm{mg} / \mathrm{L}$ bovine brain extract (Clonetics)

\section{Scrape Wound Assay}

Cells from passage 5-7 were grown to confluence in a 6-well tissue culture plate and then switched to low serum medium (LSM; 0.1\% FBS, $1 \%$ ABAM in MCDB 131 medium) with $10 \mathrm{ng} / \mathrm{mL}$ VEGF and $0.4 \%$ FAF-BSA $12 \mathrm{~h}$ prior to the start of the experiment (the VEGF was added to enhance survival of cells at $24 \mathrm{~h}$ associated with low serum medium). A $1000 \mu \mathrm{L}$ pipette tip was used to make a vertical and a horizontal scrape wound in each well, crossing near the middle of the well. Each well was washed $3 x$ with PBS to remove non-adherent cells. At the start of the experiment, pictures were taken at $4 x$ magnification on each arm of the scrape wound and $20 \mu \mathrm{L}$ PEG gels were then added to the appropriate wells. Pictures were taken again after $24 \mathrm{~h}$, using calipers on the microscope to locate the same locations. Image-Pro Express software was used to define the initial scrape wound area and the number of cells within the wound area was counted manually.

\section{Chorioallantoic Membrane (CAM) Assay}

Embryonated chicken eggs were incubated blunt-end up in a $37^{\circ} \mathrm{C}$ incubator. At embryonal day 6 , the top of the egg was cracked and removed using tweezers to create a $1.5 \mathrm{~cm}$ diameter opening. The inner shell membrane was removed, exposing the CAM. A $20 \mu \mathrm{L}$ PEG hydrogel was then placed onto the CAM. As controls, $50 \mathrm{ng}$ bFGF or $50 \mathrm{ng} \mathrm{S} 1 \mathrm{P}$ were spotted onto small pieces of Thermanox coverslips (Nunc), air dried and placed onto the CAM. The eggs were sealed with parafilm and returned to the incubator. After two days of incubation, the eggs were reopened and the degree of angiogenesis was visually assessed. ${ }^{36}$

\section{Sulforhodamine Release}

Sulforhodamine B (500 nmol) was preloaded into gels formed with PEG-OVS crosslinked with albumin, PEG-diamine, or DTT. The release experiment was run using the same protocol as the $\left[{ }^{32} \mathrm{P}\right] \mathrm{S} 1 \mathrm{P}$ release experiments described above, with detection by visible light spectroscopy at $554 \mathrm{~nm}$.

\section{Individual Cell Tracking}

PEG-OVS (3.4 mg in $20 \mu \mathrm{L}$ ) was reacted for 30 min with acetyl-GCGYGRGDSPG- $\mathrm{NH}_{2}$ peptide, to attach the peptide to $1 / 20$ of the vinyl sulfone groups (2.78 mM RGD peptide in the final hydrogel). The PEG hydrogels were crosslinked by reacting PEG-OVS with albumin (5.2 $\mathrm{mg}$ in $30 \mu \mathrm{L})$ premixed with S1P $(5 \mathrm{nmol})$ to give a final concentration of $100 \mu \mathrm{M} \mathrm{S1P}$ within the crosslinked hydrogel. The resulting solution $(50 \mu \mathrm{L})$ was pipetted into a $24-w e l l$ plate and incubated at $37^{\circ} \mathrm{C}$ for $24 \mathrm{~h}$ to allow crosslinking. HUVEC from passage 5-7 were seeded onto the gels at a concentration of $1000 \mathrm{cell} / \mathrm{cm}^{2}$. After allowing the cells to spread for $6 \mathrm{~h}$ in complete growth medium, HEPES-buffered low serum medium (MCDB 131 with $0.1 \%$ FBS, $1 \%$ ABAM, $10 \mu \mathrm{M}$ HEPES, pH 7.4) containing 0.4\% FAF-BSA was added to the cells. The cells were tracked using time-lapse microscopy for $12 \mathrm{~h}$, recording images every two minutes. Individual cell migration speeds were analyzed manually using ImageJ to trace the path of each cell over time. The time increment between analysis was increased to six minutes if cells maintained a straight path in the three consecutive images. 


\section{Results}

\section{PEG gel formation and characterization}

We synthesized PEG-OVS using a four step method, based on the methods of Morpurgo et al. 34 Each step of the synthesis gave about an $80 \%$ yield of product, and the extent of endgroup modifications were measured using NMR following each step (Fig. 1a). NMR on the final product, PEG-OVS, showed $74.7 \%$ endgroup conversion to vinyl sulfone (Fig. 1b), with 18.8\% of the endgroups present as mesylates. Considering that conversion to the hydroxymethyl sulfide was only $80 \%$ complete, it is likely that the mesylates are attached to carbons that are beta to ether groups, not sulfones. Thus, the product is only nominally octavinyl sulfone, with typically 6 vinyl sulfones and 1-2 mesylate groups per polymer chain. The mesylates may hydrolyze before reaction or may contribute to the crosslinking reaction.

PEG-OVS was crosslinked with molecules containing two or more thiols or amines, forming hydrogels via conjugate addition reactions (i.e. Michael-type addition). At $37{ }^{\circ} \mathrm{C}$, PEG-OVS formed a gel with a thiol crosslinker, DTT, in less than $10 \mathrm{~min}$ (at pH 7.4) and with amine crosslinkers in approximately $16 \mathrm{~h}(\mathrm{at} \mathrm{pH}$ 8.5). The swelling properties of the hydrogels were determined for the different crosslinkers. Gels crosslinked with proteins swelled less than gels crosslinked with bifunctional crosslinkers, indicating that at least some of the protein molecules served as elastically-active crosslink sites (Fig. 2a). Additionally, PEG-OVS/albumin hydrogels swelled less than PEG-OVS/fibrinogen hydrogels. PEG-OVS/albumin gels were exceptional in that they did not appreciably swell or shrink from the volume at which they were crosslinked. This property allowed us to covalent couple these hydrogels to surfaces during crosslinking, leading to gels whose surfaces did not appreciably deform following addition to excess solvent. Typically, gels attached to surfaces during crosslinking will wrinkle or tear while reaching equilibrium swelling volumes.

The mesh size of PEG-OVS/albumin hydrogels was investigated using SDS-PAGE with a PEG-OVS/albumin hydrogel polymerized into the acrylamide gel. Albumin migration through the PEG gel was hindered, resulting in an accumulation of albumin above the PEG layer (Fig. 2c). Thus, the mesh size of the hydrogels, which is characterized by the radius of gyration of the polymer chains between elastically-active crosslinks, is less than or on the order of the radius of gyration of albumin (about $30 \AA$ ). ${ }^{37}$ The molecular weight markers aprotinin (6.5 $\mathrm{kDa})$ and lysozyme (14.4 kDa) freely passed through the PEG gel (data not shown).

\section{Loading PEG hydrogels with S1P}

S1P was loaded into the PEG hydrogels using two techniques, postloading and preloading. For postloading, previously formed PEG hydrogels were placed in solutions containing S1P and $0.01 \%(\mathrm{w} / \mathrm{v})$ FAF-BSA. The FAF-BSA in solution was necessary to solubilize the S1P, but the concentration of albumin in the loading solution was much lower than the concentration of albumin in the hydrogel $(10 \% \mathrm{w} / \mathrm{v})$. For preloading, S1P was solubilized directly into the albumin solution used to crosslink the PEG-OVS. After S1P loading, the gels were washed with PBS three times over $26 \mathrm{~h}$ to remove weakly-bound S1P, unbound S1P or S1P attached to albumin molecules that were not crosslinked within the gel.

\section{PEG gels postloaded with S1P}

Thin layer chromatography was used to analyze the release of S1P from postloaded hydrogels. Most of the S1P was washed out of PEG-OVS/PEG-diamine hydrogels in the first $1 \mathrm{~h}$ wash with PBS, but PEG-OVS/albumin hydrogels retained the S1P during the washes (Fig. 3a). When the hydrogels were placed into a solution containing 0.4\% FAF-BSA, a large amount of S1P was released from the PEG-OVS/albumin hydrogels, but apparently little of the S1P remained in the PEG-OVS/PEG-diamine hydrogels to be released (Fig. 3b). 
We produced ${ }^{32} \mathrm{P}$-radiolabeled S1P to quantify loading and release of S1P with postloaded PEG-OVS/albumin hydrogels. $\left[{ }^{32} \mathrm{P}\right] \mathrm{S} 1 \mathrm{P}(5 \mathrm{nmol}$ in $1.5 \mathrm{~mL})$ was dissolved in PBS containing $0.01 \%$ FAF-BSA and incubated with $50 \mu \mathrm{L}$ hydrogels formed in the bottoms of wells of a 24well tissue culture plate. When PEG-OVS/albumin hydrogels were incubated with $1.5 \mathrm{~mL}$ of the $3.33 \mu \mathrm{M}$ S1P solution, $59.1 \pm 3.1 \%$ of the $\left[{ }^{32} \mathrm{P}\right] \mathrm{S} 1 \mathrm{P}$ in solution was captured in the gel within $24 \mathrm{~h}$. The gels were then washed thoroughly with PBS for $26 \mathrm{~h}$, with $6.9 \pm 1.1 \%$ of the loaded S1P released into the wash solutions. PBS containing 0.4\% FAF-BSA was added to the gels and controlled release of S1P from the gels was observed, with $46.6 \pm 0.4 \%$ of the remaining S1P released over $24 \mathrm{~h}$ (Fig. 3c).

An in vitro scrape wound assay 38 was used to demonstrate that S1P released from postloaded gels promoted endothelial cell migration. S1P-loaded PEG gels were placed into tissue culture wells containing scrape-wounded HUVEC in low serum medium supplemented with $10 \mathrm{ng} /$ $\mathrm{mL}$ VEGF and $0.4 \% \mathrm{w} / \mathrm{v}$ FAF-BSA. The hydrogels were allowed to freely float in the medium. PEG-OVS/albumin gels postloaded with S1P significantly increased the number of endothelial cells that migrated into the scrape wound area by $24 \mathrm{~h}$, compared to wells without gels, gels not loaded with S1P, or PEG-OVS/fibrinogen or PEG-OVS/PEG-diamine hydrogels postloaded with S1P (Fig. 4). Considering the results in Fig. 3a, the S1P loaded in the fibrinogen and diamine crosslinked hydrogels was likely removed during the washing steps.

A chick CAM assay was used to demonstrate the ability of S1P-releasing hydrogels to induce angiogenesis in vivo. PEG hydrogels were placed onto the CAM on embryonic day 6 and the extent of the angiogenic response was determined two days later. As controls, bFGF or S1P were spotted on Thermonox coverslips, eliciting a strong angiogenic response (Fig. 5a). PEGOVS/albumin gels not loaded with S1P did not induce an angiogenic response, while PEGOVS/PEG-diamine gels postloaded with S1P and washed with PBS for $26 \mathrm{~h}$ exhibited at most a modest angiogenic response. However, PEG-OVS/albumin hydrogels postloaded with S1P induced a moderate to strong angiogenic response (Fig. 5b). Two independent replicates are shown for each condition.

\section{PEG gels preloaded with S1P}

Release of S1P from preloaded PEG-OVS/albumin hydrogels was quantified using [ $\left.{ }^{32} \mathrm{P}\right] \mathrm{S} 1 \mathrm{P}$. The hydrogels were formed in the bottoms of the wells of a 24-well plate. The formed gels were washed with PBS over $26 \mathrm{~h}$ and then incubated with solutions containing different concentrations of albumin in PBS. S1P release into PBS alone was limited, while the rate of release increased with higher concentrations of albumin in solution (Fig. 6a). Controlled release was observed, with $33.8 \pm 1.5 \%$ of the $\mathrm{S} 1 \mathrm{P}$ remaining in the gel after washing released into $4 \%$ FAF-BSA in $24 \mathrm{~h}$, and $26.0 \pm 0.5 \%$ of the S1P released into $0.4 \%$ FAF-BSA in $24 \mathrm{~h}$. S1P release into human platelet poor plasma, which contains approximately $4 \%$ albumin, displayed release kinetics similar to $0.4 \%$ FAF-BSA in PBS. This may be due to competition of S1P released from the hydrogels with lipids already bound to albumin and lipoproteins in plasma.

The effect of gel mesh size on the diffusion of small molecules was tested using a water-soluble dye molecule, sulforhodamine B. The dye was preloaded into PEG-OVS/albumin hydrogels and released into PBS. The molecular weight of sulforhodamine is 580.7, compared to 379.5 for S1P, and the diffusivity of the dye would be expected to be lower than that of S1P. Using the Wilke-Chang correlation (see Supplementary Materials), we calculated a diffusion coefficient of $3.42 \times 10^{-6} \mathrm{~cm}^{2} / \mathrm{sec}$ for sulforhodamine and $4.15 \times 10^{-6} \mathrm{~cm}^{2} / \mathrm{sec}$ for S1P, both at $37{ }^{\circ} \mathrm{C}$. Release of sulforhodamine $\mathrm{B}$ from the hydrogels was rapid, nearing completion in 6 $\mathrm{h}$ (Fig. 6c), indicating that the mesh size of the PEG-OVS/albumin gels does not greatly affect the release of small molecules. 
We used time-lapse microscopy to quantify endothelial cell migration speeds on PEG-OVS/ albumin hydrogels containing RGD peptide and preloaded with S1P. RGD peptide was added to the PEG hydrogels to promote endothelial cell adhesion and spreading on the materials. After endothelial cells were seeded on the gels, the gels were incubated with complete medium for $6 \mathrm{~h}$ containing $2 \%$ serum (with a total albumin concentration of about $0.08 \%$ ). Over the next $12 \mathrm{~h}$, cell migration rates were measured in low serum medium containing $0.4 \%$ FAFBSA. Based on release between $32 \mathrm{~h}$ and $44 \mathrm{~h}$ in Fig. 6a, the S1P concentration in the low serum medium increased from less than $1 \mathrm{nM}$ (low serum medium contained $0.1 \% \mathrm{FBS}$, and FBS contains $142 \mathrm{nM} \mathrm{S1} \mathrm{P}^{28}$ ) to at least $303 \mathrm{nM}$ by the end of the migration experiment. Cell migration speeds were measured for HUVEC on $50 \mu \mathrm{L}$ PEG/albumin/RGD hydrogels formed on the bottoms of wells of a 24-well tissue culture plate. Delivery of S1P from the hydrogels increased the mean migration speeds of HUVEC from $19.2 \pm 10.1 \mu \mathrm{m} / \mathrm{h}$ to $43.8 \pm 15.7 \mu \mathrm{m} / \mathrm{h}$ (Fig. 7). The addition of culture medium containing $100 \mathrm{nM} \mathrm{S1P}$ increased the mean migration speed to only $30.2 \pm 11.8 \mu \mathrm{m} / \mathrm{h}$.

\section{Analysis of S1P release data}

An equilibrium binding constant for the interaction between S1P and albumin has not been reported. Additionally, reported values for equilibrium binding constants for interactions between lipids and proteins often vary by an order of magnitude. ${ }^{39}$ The albumin concentration in each PEG-OVS/albumin gel was $1.51 \mathrm{mM}(76 \mathrm{nmol}$ in $50 \mu \mathrm{L})$ and the initial S1P concentration in the preloaded gels was $100 \mu \mathrm{M}(5 \mathrm{nmol})$. The concentration of albumin in the $0.4 \%$ FAF-BSA release solution was $60.2 \mu \mathrm{M}(75.8 \mathrm{nmol}$ in $1.5 \mathrm{~mL})$. Assuming equilibrium dissociation constants ranging from $1 \mathrm{nM}$ to $10 \mu \mathrm{M}$, we determined that S1P release from the gels did not reach equilibrium at any of the experimental timepoints in $0.4 \%$ FAF-BSA, $4 \%$ FAF-BSA or PPP (see Supplementary Materials). This indicated that S1P release was controlled by the rate of diffusion of S1P within the gel or the rate of diffusion of dissolved albumin into the gel, and not by the saturation of albumin in the release solutions with S1P.

The S1P release data were well-described by Fickian release kinetics, given by:

$$
\frac{m_{t}}{m_{\infty}}=1-\sum_{n=0}^{\infty} \frac{2}{(n+1 / 2)^{2} \pi^{2}} e^{-\left((n+1 / 2)^{2} \pi^{2} D t / b^{2}\right)}
$$

where $t$ is the time from the start of the release experiment, $m_{t}$ is the mass of S1P released up to time $t, m_{\infty}$ is the mass of S1P ultimately released at infinite time, $D$ is an effective diffusion coefficient, and $b$ is the thickness of the gel. ${ }^{40,41} \mathrm{~A}$ single parameter, the effective diffusion coefficient $D$, was adjusted to least-squares fit the release data (Fig. 6a), considering only the first 100 terms of the infinite series and implicitly assuming that the release solution served as a perfect sink. The effective diffusion coefficients are listed in Table 1.

For short time points (corresponding to less than $60 \%$ release), Fickian diffusional release from a thin polymer film can be estimated by:

$$
\frac{m_{t}}{m_{\infty}}=2\left[\frac{D t}{\pi b^{2}}\right]^{1 / 2} \cdot{ }^{40}
$$

The release data were described as a function of the square root of time and fit by linear regression (Fig. 6b). The coefficients of determination obtained from the linear regressions are listed in Table 1.

The equilibrium affinity constants should be determinable from our experimental system by analysis of S1P release from preloaded gels into PBS or the long-time partitioning of S1P into the gel during postloading. However, these methods would be complicated by the slow release of small amounts of unreacted albumin from the gel (see Fig. 2b). Considering the release of 
S1P from preloaded gels into the PBS washes, the largest fractional release was observed in the first $1 \mathrm{~h}$ PBS wash (3.28\%), which was more than double that observed with the 0\% FAFBSA wash (i.e. PBS) between 38 and $50 \mathrm{~h}(1.45 \%)$. Using the fractional release into $0 \% \mathrm{FAF}-$ BSA between 38 and $50 \mathrm{~h}$ as an estimate of equilibrium release led to $K_{D}=792 \mathrm{nM}$. Further analysis of the effects of $K_{D}$ on loading and release of S1P is found in Supplementary Table 1.

\section{Discussion}

Materials that promote angiogenesis are desirable for treatment of myocardial and peripheral ischemia. A variety of methods of inducing angiogenesis have been explored, including gene therapy, ${ }^{42}$ delivery of angiogenic proteins, ${ }^{43}$ and angiogenic-potentiated cell transplants. ${ }^{44}$, 45 The protein growth factors bFGF and VEGF are the most widely studied angiogenic stimulants. Studies using both of these growth factors have demonstrated induction of in vivo angiogenesis. ${ }^{14,31,46-48}$ Initial clinical trials also demonstrated an increase in vascularization. ${ }^{49-51}$ However, longer term clinical studies have shown that newly formed vessels may be unstable, leading to disintegration and little long-term improvement of function. $15,52-55$ The long-term failure of therapeutic vascularization is likely due to the rapid depletion of angiogenic factors or the lack of recruitment of mural cells to stabilize the new vessels. With numerous studies reporting this loss of functional vessels after initial vascularization, it is apparent that delivery of factors other than bFGF and VEGF will be necessary to stabilize new vessels. ${ }^{16}$ PDGF is one factor that promotes vessel stabilization. Studies utilizing the delivery of multiple growth factors, such as bFGF or VEGF to promote new vessels and PDGF to promote vessel stabilization, have demonstrated an increase in mature vasculature in animal models. ${ }^{56,57}$

Lipid factors such as S1P and lysophosphatidic acid are capable of inducing many events in angiogenesis. ${ }^{17,19}$ The primary receptor for $\mathrm{S} 1 \mathrm{P}\left(\mathrm{S} 1 \mathrm{P}_{1}\right)$ has been known to be upregulated in endothelial cells in an angiogenic phenotype since 1990.58 However, it was only in 1998 that $\mathrm{S} 1 \mathrm{P}$ was demonstrated to be the ligand for this $\mathrm{G}$ protein-coupled receptor. ${ }^{59}$ In particular, $\mathrm{S} 1 \mathrm{P}$ is vital to the stabilization of vessels following angiogenesis. ${ }^{24,60,61}$ Knockout of $\mathrm{S} \mathrm{P}_{1}$ is embryonic lethal in mice, due to improper vessel maturation. ${ }^{25}$ Since S1P is capable of promoting the earlier steps of angiogenesis, such as endothelial cell migration, ${ }^{20,27,62}$ proliferation, 18 and entubulation, ${ }^{17,19,22}$ as well as the later steps of vessel maturation, it may be more effective to deliver S1P than combinations of protein growth factors. Furthermore, many studies have found that S1P also serves to protect myocardial cells from cell death induced by ischemia. ${ }^{63-66}$

We demonstrated that the interaction of S1P with albumin immobilized in our materials is necessary to control the rate of S1P release from the PEG hydrogels. However, the specific manner in which the release is controlled is still unknown. Our experiments using $0 \%, 0.4 \%$, or $4 \%(\mathrm{w} / \mathrm{v})$ FAF-BSA solutions demonstrated that the concentration of albumin in solution impacts the rate of S1P release. We used S1P release into PPP to simulate release into blood in the body, which has a normal albumin range of 3.5-4.6 g/dL $(3.5-4.6 \%(\mathrm{w} / \mathrm{v})) .67,68$ Although $4 \%$ albumin is within the normal concentration range of blood, the data for release into PPP indicated that the rate of S1P release into blood may actually be more similar to release into $0.4 \%$ FAF-BSA, possibly due to lipids already bound to the plasma albumin. This suggests that the availability of S1P binding sites on albumin (or other lipid carriers) in solution controlled the rate of release, perhaps simply by decreasing the concentration of free S1P at the gel/solution interface. Alternatively, if albumin in solution diffused into the hydrogel during the experiment, the increase in the rate of S1P release in higher concentrations of albumin solution may be transport of S1P through the gel by the diffusing albumin. In this case, the concentration of dissolved albumin in the gel would be a function of the concentration of 
albumin in solution and the diffusivity of albumin in the gel. However, modified SDS-PAGE indicated that the diffusion of albumin through the PEG-OVS/albumin gels is greatly restricted (Fig 2b)

If the reaction of a diffusible molecule with an immobilized component is fast relative to the diffusion of the molecule, the diffusion coefficient is effectively lowered by a factor proportional to the fraction of the molecule that is unbound at equilibrium. Thus, $D_{\text {eff }}=\frac{D}{R+1}$, where $\mathrm{R}$ is a partition coefficient equal to $\left[\mathrm{S} 1 \mathrm{P}-\mathrm{alb}_{\mathrm{i}}\right] /[\mathrm{S} 1 \mathrm{P}]$ and $\left[\mathrm{S} 1 \mathrm{P}-\mathrm{alb}_{\mathrm{i}}\right]$ is the concentration of S1P bound to the gel.41 The effective diffusion coefficient can be determined from S1P release data by equation 1 , assuming the release solution is a perfect sink. In our system, the effective diffusion constant was found to be a function of the concentration of albumin in solution. While loading of S1P onto albumin in PPP, $0.4 \%$ and $4 \%$ FAF-BSA release solutions is far from equilibrium at every time point (see Supplementary Table 2), the S1P concentration gradient between the gel and solution is likely affected by the accumulation of S1P near the interface due to the lack of mixing in the release solution. In Supplementary Figure 1, we show that the observed differences in effective diffusion coefficients for release into $0.4 \%$ and $4 \%$ FAF-BSA are explainable by differences in the concentration of free S1P at the boundary in unstirred solutions with $\mathrm{K}_{\mathrm{D}}$ on the order of $100 \mathrm{nM}$. The perfect sink condition is not achieved with 0.4 or $4 \%$ FAF-BSA; however, the error in this assumption is shown to be low for $4 \%$ FAF-BSA. Further measurements of the affinity of interactions between albumin for S1P, the rate of diffusion of albumin in the gels, or the amount of unreacted albumin in the gels will be needed to determine the mechanism of S1P release.

The biomaterials we developed may provide a new tool to promote healing and angiogenesis in ischemic tissue. By incorporating the lipid-transporter protein albumin into the hydrogels, the release of S1P was controlled by affinity interactions. The high concentration of albumin in the gels $(10 \% \mathrm{w} / \mathrm{v}, 1.51 \mu \mathrm{M})$ allowed S1P to be efficiently loaded into the gels and slowly released, even into solutions containing high concentrations of lipid transporter proteins. We demonstrated that the S1P released from the hydrogels enhanced migration of endothelial cells growing on the materials, and induced angiogenesis in the CAM model. Further development of the materials with higher affinity lipid-transporting proteins, or enzymes that produce sphingosine 1-phosphate in situ, may lead to materials that are useful in promoting angiogenesis or the endothelialization of materials following implantation.

\section{Supplementary Material}

Refer to Web version on PubMed Central for supplementary material.

\section{Acknowledgements}

We are grateful to Dr. Greg Longmore Dr. Marina Kisseleva for invaluable assistance with the [ $\left.{ }^{32} \mathrm{P}\right] \mathrm{S} 1 \mathrm{P}$ experiments. This work was supported by an NIH training grant (T32 HL07916-05) to BKW, SKH, EAS, and MMK.

\section{References}

1. Klagsbrun M, D’Amore PA. Regulators of angiogenesis. Annu Rev Physiol 1991;53:217-39. [PubMed: 1710435]

2. Hellstrom M, Kalen M, Lindahl P, Abramsson A, Betsholtz C. Role of PDGF-B and PDGFR-beta in recruitment of vascular smooth muscle cells and pericytes during embryonic blood vessel formation in the mouse. Development 1999;126(14):3047-55. [PubMed: 10375497]

3. Dvorak HF. VPF/VEGF and the angiogenic response. Semin Perinatol 2000;24(1):75-8. [PubMed: 10709865] 
4. Rhee JS, Black M, Schubert U, Fischer S, Morgenstern E, Hammes HP, Preissner KT. The functional role of blood platelet components in angiogenesis. Thromb Haemost 2004;92(2):394-402. [PubMed: 15269837]

5. Bernstein LR, Antoniades H, Zetter BR. Migration of cultured vascular cells in response to plasma and platelet-derived factors. J Cell Sci 1982;56:71-82. [PubMed: 7166578]

6. Papetti M, Herman IM. Mechanisms of normal and tumor-derived angiogenesis. Am J Physiol Cell Physiol 2002;282(5):C947-70. [PubMed: 11940508]

7. Lee H, Goetzl EJ, An S. Lysophosphatidic acid and sphingosine 1-phosphate stimulate endothelial cell wound healing. Am J Physiol Cell Physiol 2000;278(3):C612-8. [PubMed: 10712250]

8. Kevil CG, Payne DK, Mire E, Alexander JS. Vascular permeability factor/vascular endothelial cell growth factor-mediated permeability occurs through disorganization of endothelial junctional proteins. J Biol Chem 1998;273(24):15099-103. [PubMed: 9614120]

9. Maisonpierre PC, Suri C, Jones PF, Bartunkova S, Wiegand SJ, Radziejewski C, Compton D, McClain J, Aldrich TH, Papadopoulos N, Daly TJ, Davis S, Sato TN, Yancopoulos GD. Angiopoietin-2, a natural antagonist for Tie2 that disrupts in vivo angiogenesis. Science 1997;277(5322):55-60. [PubMed: 9204896]

10. Brooks PC, Clark RA, Cheresh DA. Requirement of vascular integrin alpha v beta 3 for angiogenesis. Science 1994;264(5158):569-71. [PubMed: 7512751]

11. Hockel M, Sasse J, Wissler JH. Purified monocyte-derived angiogenic substance (angiotropin) stimulates migration, phenotypic changes, and "tube formation" but not proliferation of capillary endothelial cells in vitro. J Cell Physiol 1987;133(1):1-13. [PubMed: 2444604]

12. Hendel RC, Henry TD, Rocha-Singh K, Isner JM, Kereiakes DJ, Giordano FJ, Simons M, Bonow RO. Effect of intracoronary recombinant human vascular endothelial growth factor on myocardial perfusion: evidence for a dose-dependent effect. Circulation 2000;101(2):118-21. [PubMed: 10637195]

13. Nakajima H, Sakakibara Y, Tambara K, Iwakura A, Doi K, Marui A, Ueyama K, Ikeda T, Tabata Y, Komeda M. Therapeutic angiogenesis by the controlled release of basic fibroblast growth factor for ischemic limb and heart injury: toward safety and minimal invasiveness. Journal of Artificial Organs 2004;7(2):58-61. [PubMed: 15309671]

14. Takeshita S, Pu LQ, Stein LA, Sniderman AD, Bunting S, Ferrara N, Isner JM, Symes JF. Intramuscular administration of vascular endothelial growth factor induces dose-dependent collateral artery augmentation in a rabbit model of chronic limb ischemia. Circulation 1994;90(5 Pt 2):II22834. [PubMed: 7525111]

15. Simons M, Bonow RO, Chronos NA, Cohen DJ, Giordano FJ, Hammond HK, Laham RJ, Li W, Pike M, Sellke FW, Stegmann TJ, Udelson JE, Rosengart TK. Clinical trials in coronary angiogenesis: issues, problems, consensus: An expert panel summary. Circulation 2000;102(11):E73-86. [PubMed: 10982554]

16. Yancopoulos GD, Davis S, Gale NW, Rudge JS, Wiegand SJ, Holash J. Vascular-specific growth factors and blood vessel formation. Nature 2000;407(6801):242-8. [PubMed: 11001067]

17. Lee OH, Kim YM, Lee YM, Moon EJ, Lee DJ, Kim JH, Kim KW, Kwon YG. Sphingosine 1phosphate induces angiogenesis: its angiogenic action and signaling mechanism in human umbilical vein endothelial cells. Biochem Biophys Res Commun 1999;264(3):743-50. [PubMed: 10544002]

18. English D, Welch Z, Kovala AT, Harvey K, Volpert OV, Brindley DN, Garcia JG. Sphingosine 1phosphate released from platelets during clotting accounts for the potent endothelial cell chemotactic activity of blood serum and provides a novel link between hemostasis and angiogenesis. Faseb J 2000;14(14):2255-65. [PubMed: 11053247]

19. Hla T. Physiological and pathological actions of sphingosine 1-phosphate. Semin Cell Dev Biol 2004;15(5):513-20. [PubMed: 15271296]

20. Langlois S, Gingras D, Beliveau R. Membrane type 1-matrix metalloproteinase (MT1-MMP) cooperates with sphingosine 1-phosphate to induce endothelial cell migration and morphogenic differentiation. Blood 2004;103(8):3020-8. [PubMed: 15070679]

21. Bayless KJ, Davis GE. Sphingosine-1-phosphate markedly induces matrix metalloproteinase and integrin-dependent human endothelial cell invasion and lumen formation in three-dimensional 
collagen and fibrin matrices. Biochem Biophys Res Commun 2003;312(4):903-13. [PubMed: 14651957]

22. Lee MJ, Thangada S, Claffey KP, Ancellin N, Liu CH, Kluk M, Volpi M, Sha'afi RI, Hla T. Vascular endothelial cell adherens junction assembly and morphogenesis induced by sphingosine-1phosphate. Cell 1999;99(3):301-12. [PubMed: 10555146]

23. McVerry BJ, Garcia JG. Endothelial cell barrier regulation by sphingosine 1-phosphate. J Cell Biochem 2004;92(6):1075-85. [PubMed: 15258893]

24. Paik JH, Skoura A, Chae SS, Cowan AE, Han DK, Proia RL, Hla T. Sphingosine 1-phosphate receptor regulation of N-cadherin mediates vascular stabilization. Genes Dev 2004;18(19):2392-2403. [PubMed: 15371328]

25. Liu Y, Wada R, Yamashita T, Mi Y, Deng CX, Hobson JP, Rosenfeldt HM, Nava VE, Chae SS, Lee MJ, Liu CH, Hla T, Spiegel S, Proia RL. Edg-1, the G protein-coupled receptor for sphingosine-1phosphate, is essential for vascular maturation. J Clin Invest 2000;106(8):951-61. [PubMed: 11032855]

26. Kimura T, Sato K, Malchinkhuu E, Tomura H, Tamama K, Kuwabara A, Murakami M, Okajima F. High-density lipoprotein stimulates endothelial cell migration and survival through sphingosine 1phosphate and its receptors. Arterioscler Thromb Vasc Biol 2003;23(7):1283-8. [PubMed: 12775579]

27. Yatomi Y, Ohmori T, Rile G, Kazama F, Okamoto H, Sano T, Satoh K, Kume S, Tigyi G, Igarashi Y, Ozaki Y. Sphingosine 1-phosphate as a major bioactive lysophospholipid that is released from platelets and interacts with endothelial cells. Blood 2000;96(10):3431-8. [PubMed: 11071638]

28. Murata N, Sato K, Kon J, Tomura H, Yanagita M, Kuwabara A, Ui M, Okajima F. Interaction of sphingosine 1-phosphate with plasma components, including lipoproteins, regulates the lipid receptor-mediated actions. Biochem J 2000;352(Pt 3):809-15. [PubMed: 11104690]

29. Gayet JC, Fortier G. Drug release from new bioartificial hydrogel. Artif Cells Blood Substit Immobil Biotechnol 1995;23(5):605-11. [PubMed: 8528454]

30. Alcantar NA, Aydil ES, Israelachvili JN. Polyethylene glycol-coated biocompatible surfaces. J Biomed Mater Res 2000;51(3):343-51. [PubMed: 10880075]

31. Zisch AH, Lutolf MP, Ehrbar M, Raeber GP, Rizzi SC, Davies N, Schmokel H, Bezuidenhout D, Djonov V, Zilla P, Hubbell JA. Cell-demanded release of VEGF from synthetic, biointeractive cell ingrowth matrices for vascularized tissue growth. Faseb J 2003;17(15):2260-2. [PubMed: 14563693]

32. Elbert DL, Hubbell JA. Conjugate addition reactions combined with free-radical cross-linking for the design of materials for tissue engineering. Biomacromolecules 2001;2(2):430-41. [PubMed: 11749203]

33. Masri MS, Friedman M. Protein reactions with methyl and ethyl vinyl sulfones. J Protein Chem 1988;7 (1):49-54. [PubMed: 2475130]

34. Morpurgo M, Veronese FM, Kachensky D, Harris JM. Preparation of characterization of poly (ethylene glycol) vinyl sulfone. Bioconjug Chem 1996;7(3):363-8. [PubMed: 8816961]

35. Olivera A, Kohama T, Tu Z, Milstien S, Spiegel S. Purification and characterization of rat kidney sphingosine kinase. J Biol Chem 1998;273(20):12576-83. [PubMed: 9575218]

36. Ponce, ML.; Kleinman, HK. The chick chorioallantoic membrane as an in vivo angiogenesis model. In: Yamada, KM., editor. Current Protocols in Cell Biology. John Wiley \& Sons, Inc.; New York: 2003. p. 19.5.1-19.5.6.

37. Tyn MT, Gusek TW. Prediction of diffusion coefficients of proteins. BIOTECHNOL BIOENG 1990;35(4):327-338. [PubMed: 18592527]

38. Hughes S, Wacker B, Kaneda M, Elbert D. Fluid Shear Stress Modulates Cell Migration Induced by Sphingosine 1-Phosphate and Vascular Endothelial Growth Factor. Annals of Biomedical Engineering 2005;33(8):1003-1014. [PubMed: 16133909]

39. Elmadhoun BM, Wang GQ, Templeton JF, Burczynski FJ. Binding of [3H]palmitate to BSA. Am J Physiol 1998;275(4 Pt 1):G638-44. [PubMed: 9756491]

40. Ritger PL, Peppas NA. A simple equation for description of solute release I. Fickian and non-fickian release from non-swellable devices in the form of slabs, spheres, cylinders or discs. Journal of Controlled Release 1987;5(1):23-36.

41. Crank, J. The mathematics of diffusion. 2. Clarendon Press; Oxford: 1975. p. ixp. 414 
42. Khan TA, Sellke FW, Laham RJ. Gene therapy progress and prospects: therapeutic angiogenesis for limb and myocardial ischemia. Gene Ther 2003;10(4):285-91. [PubMed: 12595887]

43. Freedman SB, Isner JM. Therapeutic angiogenesis for coronary artery disease. Ann Intern Med 2002;136(1):54-71. [PubMed: 11777364]

44. Losordo DW, Dimmeler S. Therapeutic angiogenesis and vasculogenesis for ischemic disease: part II: cell-based therapies. Circulation 2004;109(22):2692-7. [PubMed: 15184293]

45. Scheinowitz M. Therapeutic myocardial angiogenesis: past, present and future. Mol Cell Biochem 2004;264(1-2):75-83. [PubMed: 15544037]

46. Lee KY, Peters MC, Mooney DJ. Comparison of vascular endothelial growth factor and basic fibroblast growth factor on angiogenesis in SCID mice. J Control Release 2003;87(1-3):49-56. [PubMed: 12618022]

47. Sakakibara Y, Tambara K, Sakaguchi G, Lu F, Yamamoto M, Nishimura K, Tabata Y, Komeda M. Toward surgical angiogenesis using slow-released basic fibroblast growth factor. Eur J Cardiothorac Surg 2003;24(1):105-11. 112. [PubMed: 12853053]

48. Nor JE, Christensen J, Mooney DJ, Polverini PJ. Vascular endothelial growth factor (VEGF)mediated angiogenesis is associated with enhanced endothelial cell survival and induction of Bcl-2 expression. Am J Pathol 1999;154(2):375-84. [PubMed: 10027396]

49. Sellke FW, Laham RJ, Edelman ER, Pearlman JD, Simons M. Therapeutic angiogenesis with basic fibroblast growth factor: technique and early results. Ann Thorac Surg 1998;65(6):1540-4. [PubMed: 9647055]

50. Henry TD, Annex BH, McKendall GR, Azrin MA, Lopez JJ, Giordano FJ, Shah PK, Willerson JT, Benza RL, Berman DS, Gibson CM, Bajamonde A, Rundle AC, Fine J, McCluskey ER. The VIVA trial: Vascular endothelial growth factor in Ischemia for Vascular Angiogenesis. Circulation 2003;107(10):1359-65. [PubMed: 12642354]

51. Laham RJ, Garcia L, Baim DS, Post M, Simons M. Therapeutic Angiogenesis Using Basic Fibroblast Growth Factor and Vascular Endothelial Growth Factor Using Various Delivery Strategies. Curr Interv Cardiol Rep 1999;1(3):228-233. [PubMed: 11096629]

52. Darland DC, D'Amore PA. Blood vessel maturation: vascular development comes of age. J Clin Invest 1999;103(2):157-8. [PubMed: 9916126]

53. Isner JM, Pieczek A, Schainfeld R, Blair R, Haley L, Asahara T, Rosenfield K, Razvi S, Walsh K, Symes JF. Clinical evidence of angiogenesis after arterial gene transfer of phVEGF165 in patient with ischaemic limb. Lancet 1996;348(9024):370-4. [PubMed: 8709735]

54. Ng YS, D'Amore PA. Therapeutic angiogenesis for cardiovascular disease. Curr Control Trials Cardiovasc Med 2001;2(6):278-285. [PubMed: 11806814]

55. Simons M, Annex BH, Laham RJ, Kleiman N, Henry T, Dauerman H, Udelson JE, Gervino EV, Pike M, Whitehouse MJ, Moon T, Chronos NA. Pharmacological treatment of coronary artery disease with recombinant fibroblast growth factor-2: double-blind, randomized, controlled clinical trial. Circulation 2002;105(7):788-93. [PubMed: 11854116]

56. Cao R, Brakenhielm E, Pawliuk R, Wariaro D, Post MJ, Wahlberg E, Leboulch P, Cao Y. Angiogenic synergism, vascular stability and improvement of hind-limb ischemia by a combination of PDGFBB and FGF-2. Nat Med 2003;9(5):604-13. [PubMed: 12669032]

57. Richardson TP, Peters MC, Ennett AB, Mooney DJ. Polymeric system for dual growth factor delivery. Nat Biotechnol 2001;19(11):1029-34. [PubMed: 11689847]

58. Hla T, Maciag T. An abundant transcript induced in differentiating human endothelial cells encodes a polypeptide with structural similarities to G-protein-coupled receptors. J Biol Chem 1990;265(16): 9308-13. [PubMed: 2160972]

59. Lee MJ, Van Brocklyn JR, Thangada S, Liu CH, Hand AR, Menzeleev R, Spiegel S, Hla T. Sphingosine-1-phosphate as a ligand for the G protein-coupled receptor EDG-1. Science 1998;279 (5356):1552-5. [PubMed: 9488656]

60. McVerry BJ, Garcia JG. In vitro and in vivo modulation of vascular barrier integrity by sphingosine 1-phosphate: mechanistic insights. Cell Signal 2005;17(2):131-9. [PubMed: 15494205]

61. Allende ML, Yamashita T, Proia RL. G-protein-coupled receptor S1P1 acts within endothelial cells to regulate vascular maturation. Blood 2003;102(10):3665-7. [PubMed: 12869509] 
62. Wang F, Van Brocklyn JR, Hobson JP, Movafagh S, Zukowska-Grojec Z, Milstien S, Spiegel S. Sphingosine 1-phosphate stimulates cell migration through a G(i)-coupled cell surface receptor. Potential involvement in angiogenesis. J Biol Chem 1999;274(50):35343-50. [PubMed: 10585401]

63. Jin ZQ, Goetzl EJ, Karliner JS. Sphingosine kinase activation mediates ischemic preconditioning in murine heart. Circulation 2004;110(14):1980-9. [PubMed: 15451787]

64. Jin ZQ, Zhou HZ, Zhu P, Honbo N, Mochly-Rosen D, Messing RO, Goetzl EJ, Karliner JS, Gray MO. Cardioprotection mediated by sphingosine-1-phosphate and ganglioside GM-1 in wild-type and PKC epsilon knockout mouse hearts. Am J Physiol Heart Circ Physiol 2002;282(6):H1970-7. [PubMed: 12003800]

65. Karliner JS. Mechanisms of cardioprotection by lysophospholipids. J Cell Biochem 2004;92(6):1095103. [PubMed: 15258895]

66. Karliner JS, Honbo N, Summers K, Gray MO, Goetzl EJ. The lysophospholipids sphingosine-1phosphate and lysophosphatidic acid enhance survival during hypoxia in neonatal rat cardiac myocytes. J Mol Cell Cardiol 2001;33(9):1713-7. [PubMed: 11549349]

67. Feldman M, Soni N, Dickson B. Influence of hypoalbuminemia or hyperalbuminemia on the serum anion gap. J Lab Clin Med 2005;146(6):317-20. [PubMed: 16310513]

68. Cole A, Mendelblatt D, Aguayo J, Mathew A, Martin E, Vesely DL. Metastatic prostate cancer (with prostate-specific antigen of 9996) presenting as obstructive jaundice. Am J Med Sci 2000;319(2): 118-22. [PubMed: 10698097] 
$\mathbf{a}$

\begin{tabular}{|l|r|r|}
\hline 8-arm PEG & $\begin{array}{r}\text { Endgroup } \\
\text { Conversion (\%) }\end{array}$ & Yield (\%) \\
\hline PEG-mesylate & 99.1 & 82.2 \\
\hline PEG-hydroxyethyl sulfide & 80.1 & 88.1 \\
\hline PEG-hydroxyethyl sulfone & 84.0 & 85.1 \\
\hline PEG-vinyl sulfone & 84.4 & 78.5 \\
\hline
\end{tabular}

b

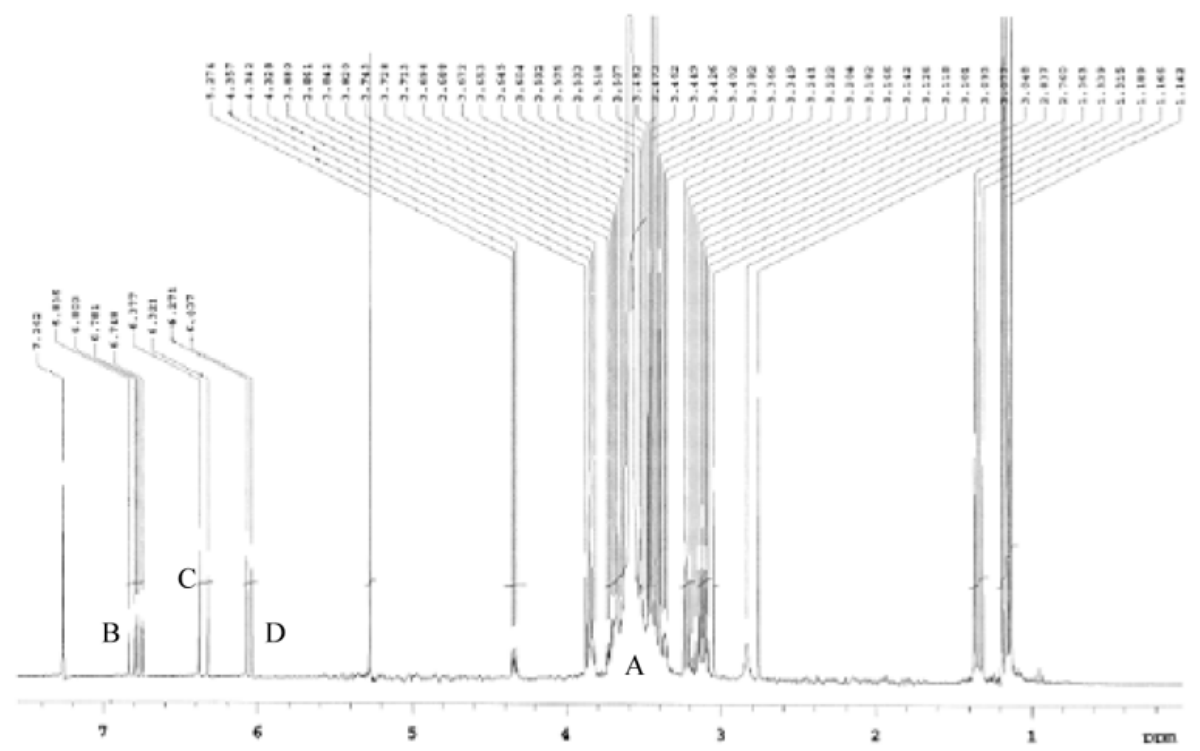

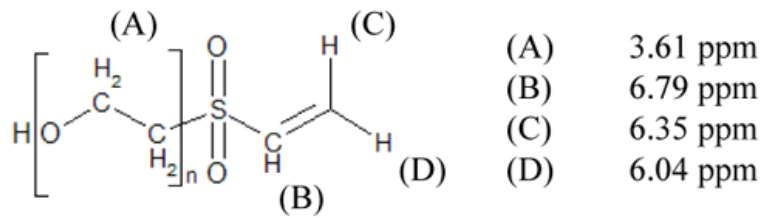

Figure 1.

Synthesis of PEG-octavinylsulfone. PEG-octavinylsulfone was synthesized using a 4-step process from eight-arm PEG (mol. wt. 10,000). a) The percentage of endgroup conversion for each step in the PEG-octavinylsulfone synthesis was obtained by comparing the areas of endgroup peaks to the area of the PEG backbone peak. b) NMR of the PEG-octavinylsulfone product, with the PEG backbone peak at $3.61 \mathrm{ppm}$, and the vinyl sulfone peaks between 6 and 7 ppm. 
a

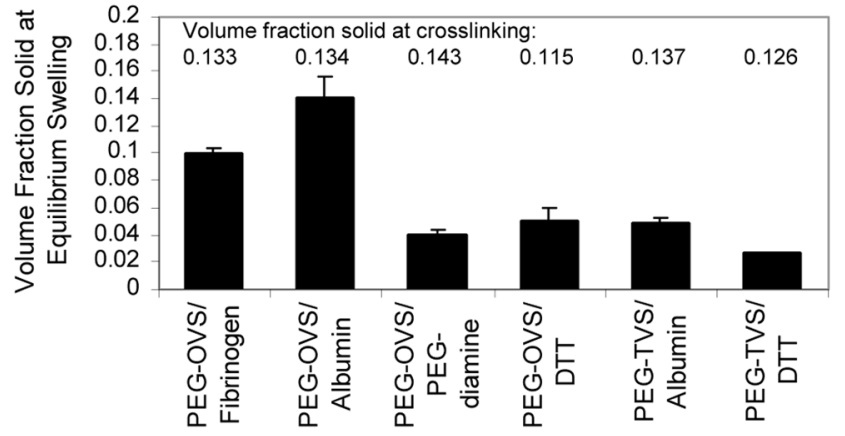

b

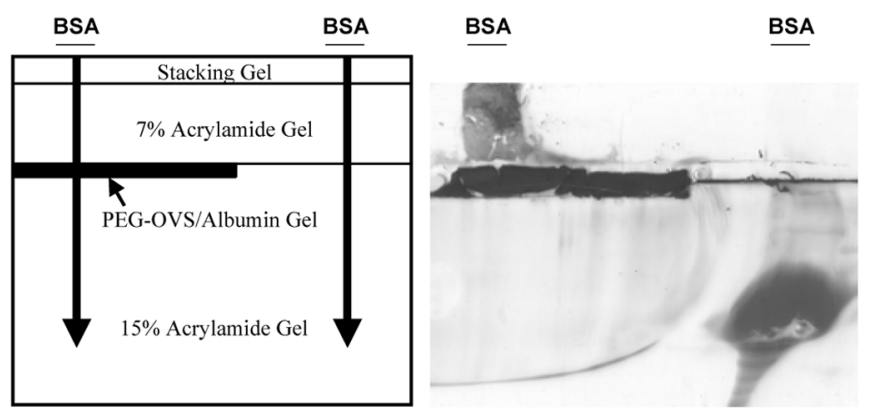

Figure 2.

Characterization of Hydrogel Crosslink Densities. a) PEG-octavinylsulfone (PEG-OVS) or PEG-tetravinylsulfone (PEG-TVS) was crosslinked with albumin, fibrinogen, PEG-diamine (mol. wt. 3400), or DTT. The percent solid in each swollen gel was calculated after 4 days of swelling in PBS, pH 7.4. The hydrogels were crosslinked at the percent solids listed above each column. Data represent mean \pm standard deviation. b) A $15 \%$ SDS-PAGE gel was polymerized, with a spacer on the top left side of the chamber. After the spacer was removed, a thin layer of PEG-OVS/albumin precursor solution was pipetted into the formed well and crosslinked for $24 \mathrm{~h}$. A 7\% SDS-PAGE gel was then polymerized to fill the rest of the casting chamber. Bovine serum albumin (BSA; $20 \mu \mathrm{g}$ in $20 \mu \mathrm{L}$ ) was loaded on the gel at the indicated locations. BSA did not pass through the PEG gel and accumulated above the hydrogel layer. Note the intense staining of the PEG-OVS/albumin gel with Coomassie Blue and the apparent migration of some proteinaceous material from the PEG gel. 
$\mathbf{a}$

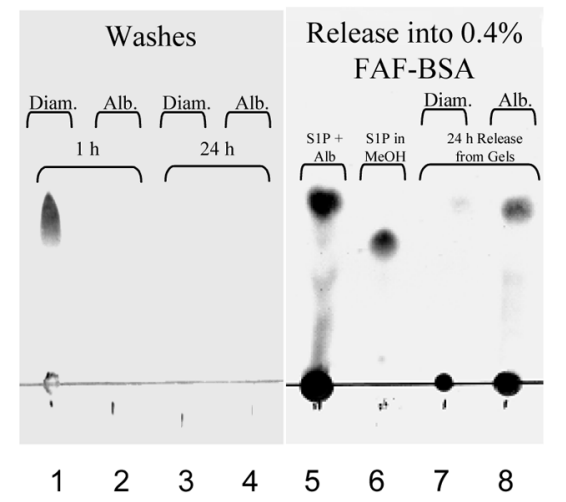

c

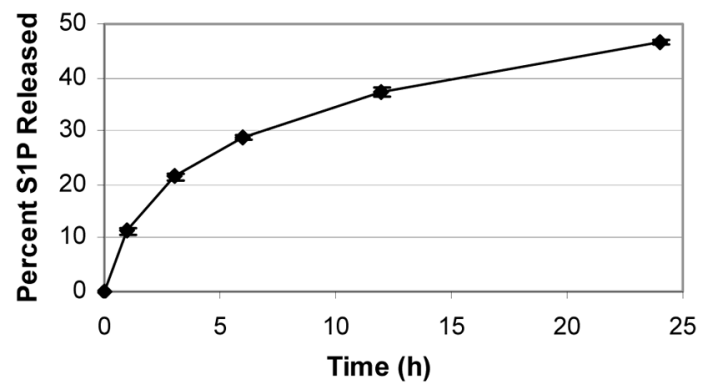

Figure 3.

S1P release from PEG hydrogels 'postloaded' with S1P. PEG hydrogels were formed by reacting PEG-OVS with albumin, fibrinogen or PEG-diamine. The crosslinked hydrogels were then 'postloaded' with S1P by incubation with $5 \mathrm{nmol} \mathrm{S1P}$ in $0.01 \%$ FAF-BSA for $24 \mathrm{~h}$ at $37^{\circ}$ $\mathrm{C}$ (all FAF-BSA solutions were in PBS, pH 7.4). This was followed by 2 washes with PBS for $1 \mathrm{~h}$, and a final wash with PBS for $24 \mathrm{~h}$. a) The contents of the first $1 \mathrm{~h}$ PBS wash and the 24 $h$ PBS wash were analyzed by thin layer chromatography for a PEG-OVS/PEG-diamine gel (Diam.) or a PEG-OVS/albumin gel (Alb.). b) After the PBS washes, the same gels were then incubated with a solution of $0.4 \%$ FAF-BSA in PBS. Lane 5 shows the control consisting of S1P dissolved in 0.4\% FAF-BSA while lane 6 shows S1P dissolved in methanol. Note the difference in $\mathrm{R}_{\mathrm{f}}$ in the presence of FAF-BSA. c) Release of S1P from PEG-OVS/albumin hydrogels was measured using $\left[{ }^{32} \mathrm{P}\right] \mathrm{S} 1 \mathrm{P}$. In $24 \mathrm{~h}$ at $37^{\circ} \mathrm{C}$, the $50 \mu \mathrm{L}$ hydrogels sequestered $59.1 \pm 3.1 \%$ of the S1P from a solution of $5 \mathrm{nmol} \mathrm{S1P}$ in $1.5 \mathrm{~mL}$ of $0.01 \%$ FAF-BSA. During the PBS washes, $6.9 \pm 1.1 \%$ of the loaded S1P was released over $26 \mathrm{~h}$. At time $=0$ in the figure, $0.4 \%$ FAF-BSA was added to the gels, leading to the release of $46.6 \pm 0.4 \%$ of the S1P in the hydrogel within $24 \mathrm{~h}$. Error bars represent std. dev. 


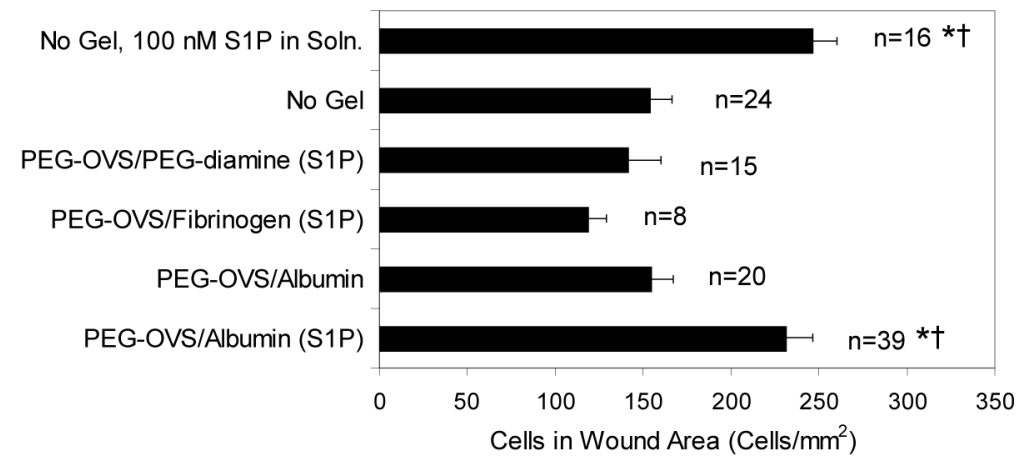

Figure 4.

A scrape wound assay was used to demonstrate the response of human umbilical vein endothelial cells to S1P released from the hydrogels. PEG-OVS/albumin gels $(20 \mu \mathrm{L})$ postloaded with S1P increased the amount of cell migration into the wound area $(p=0.01 \mathrm{vs}$. medium with no gel, $p=0.02$ vs. PEG-OVS/Albumin gels without S1P loading) to an extent similar to $100 \mathrm{nM} \mathrm{S1P}$ in medium ( $p=0.03$ vs. medium with no gel, $p=0.02$ vs. PEG-OVS/ albumin gels without S1P loading). All other experimental conditions did not cause significant differences in cell migration into the wound area versus medium alone. In the column labels, '(S1P)' denotes S1P postloaded into the hydrogels. * Statistically significant difference vs. medium with no gel. $\uparrow$ Statistically significant difference vs. PEG-OVS/albumin gels without S1P loading. Error bars represent SEM with statistical analysis by ANOVA and postprocessing with the Scheffe test. 
a

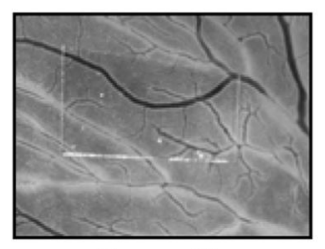

Coverslip

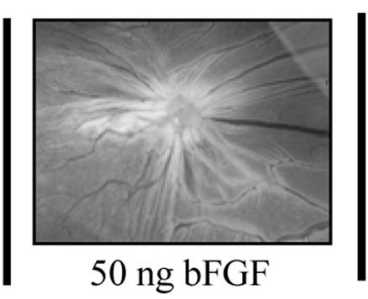

$50 \mathrm{ng}$ bFGF

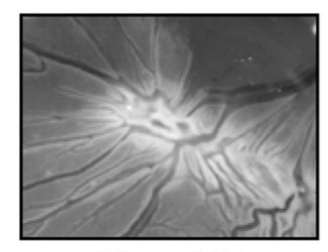

50 ng S1P

b
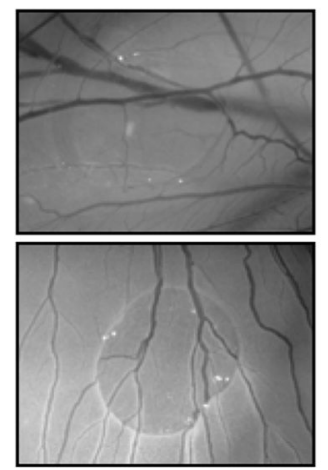

PEG-OVS/Albumin gel

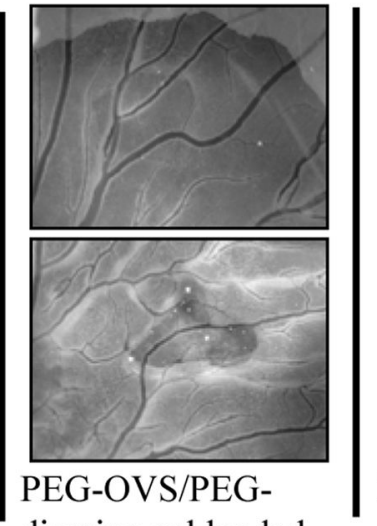

diamine gel loaded with S1P

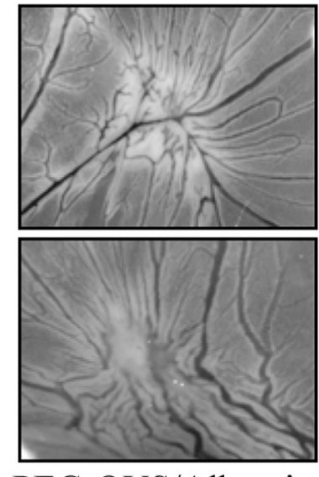

PEG-OVS/Albumin gel loaded with S1P

Figure 5.

Angiogenic response observed in CAM assay. (a) As controls, S1P or bFGF were spotted onto Thermanox coverslips, air-dried, and placed face down onto the chick chorioallantoic membrane (CAM). A strong angiogenic response was elicited by $50 \mathrm{ng}$ bFGF or $50 \mathrm{ng}$ S1P (characterized by the curvature of large vessels toward the point of stimulus). (b) A $20 \mu \mathrm{L}$ PEG-OVS/albumin hydrogel without S1P showed no angiogenic response. A PEG-OVS/PEGdiamine hydrogel loaded with $5 \mathrm{nmol} \mathrm{S1P}$ and washed with PBS for $26 \mathrm{~h}$ showed little or no angiogenic response. A PEG-OVS/albumin hydrogel loaded with $5 \mathrm{nmol} \mathrm{S1P}$ and washed with PBS for $26 \mathrm{~h}$ showed a moderate to strong angiogenic response. Results from two separate experiments are shown for each treatment. 


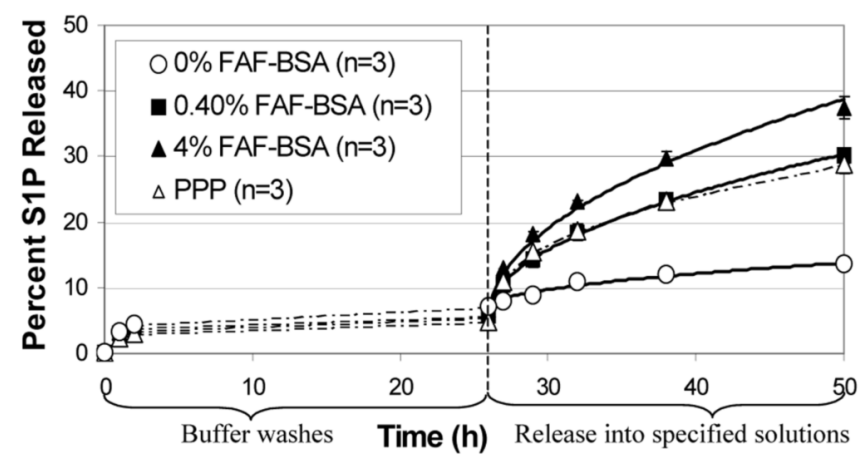

b

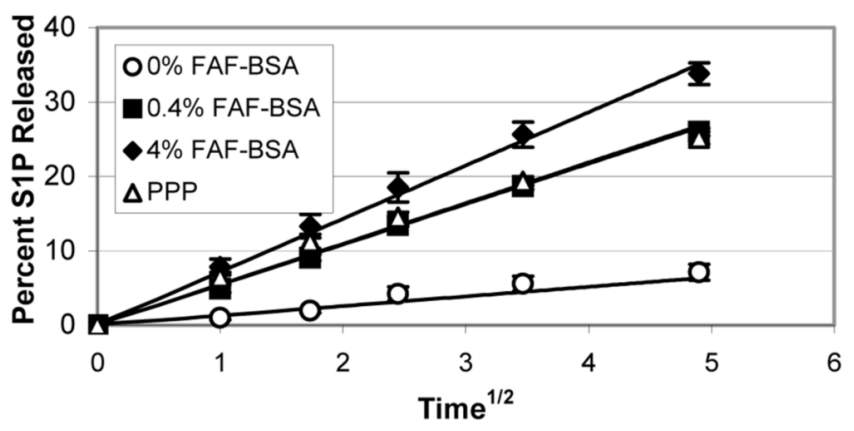

c

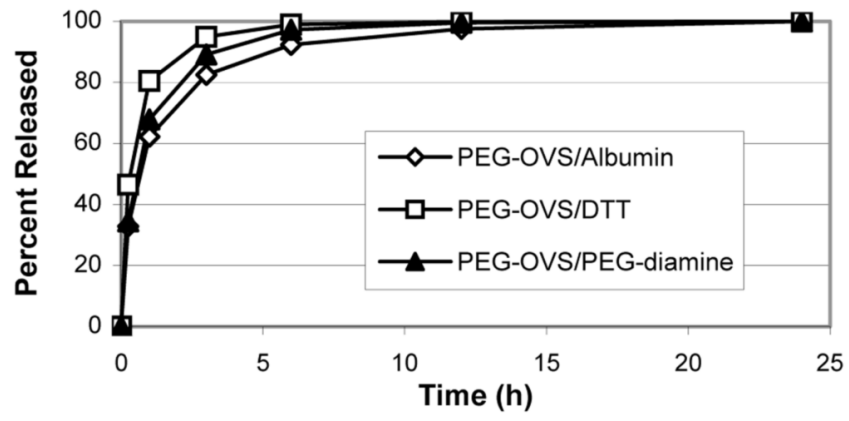

Figure 6.

S1P release from PEG gels crosslinked with albumin 'preloaded' with S1P. S1P was dissolved in PBS containing 17.5\% FAF-BSA (1 nmol S1P per mg of albumin). PEG hydrogels (50 $\mu \mathrm{L}$ ) were formed in the wells of a 24-well plate by adding PEG-OVS to the albumin/S1P solution, with a total of $5 \mathrm{nmol} \mathrm{S1P}$ present in each gel. a) The rate of S1P release was measured using $\left[{ }^{32} \mathrm{P}\right] \mathrm{S} 1 \mathrm{P}$. Approximately 5\% of the S1P in the hydrogel was released into the PBS washes over $26 \mathrm{~h}$. The rate of S1P release increased with increasing concentrations of FAF-BSA in the release solution. Release of S1P into human platelet poor plasma was similar to release into PBS containing 0.4\% FAF-BSA. Dashed lines connect data points, solid lines show least squares fits of the data to a solution of the unsteady diffusion equation (see text). A single 
parameter was adjusted in the model, an effective diffusion coefficient. Error bars represent standard deviations. b) The S1P release data was plotted as a function of (time) $)^{1 / 2}$ to determine the fit of the data to the short-time Fickian release equation (see text). c) The effect of gel crosslink density on the release of small molecules was minor compared to the effect of specific binding to albumin. Release of sulforhodamine B, a water-soluble dye molecule $50 \%$ larger than S1P, was measured from $50 \mu \mathrm{L}$ PEG-OVS/albumin gels. The dye $(500 \mathrm{nmol})$ was incubated with albumin prior to crosslinking. Release of sulforhodamine B into PBS was nearly complete in $6 \mathrm{~h}$. 


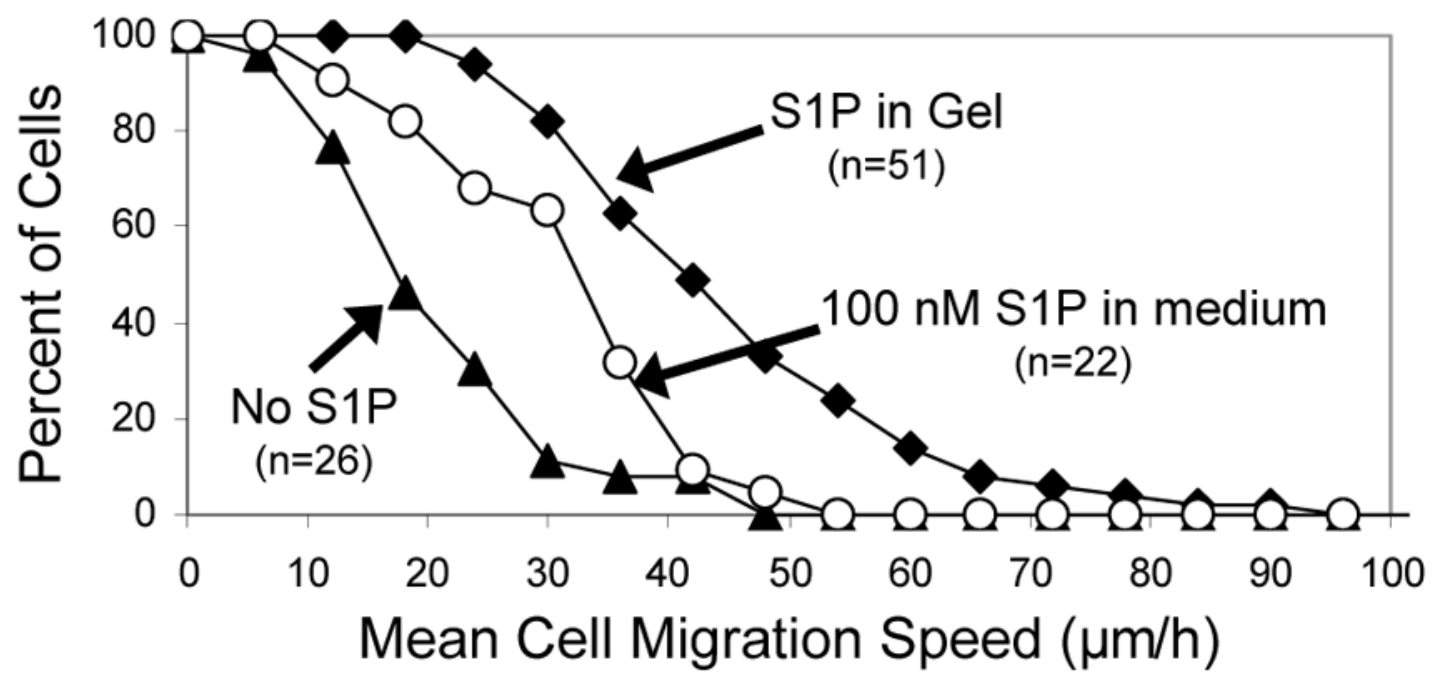

Figure 7.

Endothelial cell migration on PEG gels crosslinked with albumin 'preloaded' with S1P. S1P was dissolved into PBS containing 17.5\% FAF-BSA (1 nmol S1P per mg of albumin). PEG hydrogels $(50 \mu \mathrm{L})$ were formed in the wells of a 24-well plate by reacting PEG-OVS with the albumin/S1P solution, with $5 \mathrm{nmol} \mathrm{S} 1 \mathrm{P}$ present in each gel. RGD peptide was also added to the gels to promote cell adhesion and spreading. The migration speed of individual HUVEC seeded on PEG/albumin hydrogels containing RGD peptide was measured in the presence or absence of S1P released from the gel. Delivery of S1P from the hydrogel increased the mean migration speed of the HUVEC from $19.2 \pm 10.1 \mu \mathrm{m} / \mathrm{h}$ to $43.8 \pm 15.7 \mu \mathrm{m} / \mathrm{h}$, while addition of $100 \mathrm{nM}$ S1P to the medium above HUVEC growing on the PEG hydrogel increased the mean migration speed to $30.2 \pm 11.8 \mu \mathrm{m} / \mathrm{h}\left(p=3 \times 10^{-10}\right.$, gel $+\mathrm{S} 1 \mathrm{P}$ vs. gel w/o S1P; $p=0.0008$, gel $+\mathrm{S} 1 \mathrm{P}$ vs $100 \mathrm{nM}$ S1P; $p=0.02,100 \mathrm{nM} \mathrm{S1P}$ vs. gel w/o S1P). Error bars represent std. dev. Statistical analysis was by ANOVA with post-processing with the Scheffe test 
Table 1

Effective diffusion coefficients for S1P release from PEG-OVS/albumin hydrogels. S1P release data in Figure 6(a) was least-squares fit to a solution of the unsteady diffusion equation (see text), fitting a single parameter, the effective diffusion coefficient. The release of $\left[{ }^{32} \mathrm{P}\right] \mathrm{S} 1 \mathrm{P}$ from PEG-OVS/albumin gels was measured into $0 \%, 0.4 \%$, and $4 \%$ FAF-BSA, as well as into platelet poor plasma (PPP). Additionally, coefficients of determination are reported for linear regressions of $\mathrm{S} 1 \mathrm{P}$ release as a function of (time) $)^{1 / 2}$

\begin{tabular}{ccccc}
\hline & 0\% FAF- BSA & 0.4\% FAF- BSA & 4\% FAF- BSA & PPP \\
\hline $\begin{array}{c}\text { Effective Diffusion } \\
\text { Coefficient }(\mathrm{D})\left(\mathrm{cm}^{2} / \mathrm{sec}\right)\end{array}$ & $3.05 \times 10^{-11}$ & $3.89 \times 10^{-10}$ & $7.04 \times 10^{-10}$ & $3.89 \times 10^{-10}$ \\
$\begin{array}{c}\text { Coefficients of } \\
\left.\text { Determination( } \mathrm{R}^{2}\right)\end{array}$ & 0.972 & 0.999 & 0.996 & 0.988 \\
\hline
\end{tabular}

